Shimazaki, A., Y. Yamaura, M. Senzaki, Y. Yabuhara, and F. Nakamura 2017. Mobbing call experiment suggests the enhancement of forest bird movement by tree cover in urban landscapes across seasons. Avian Conservation and Ecology 12(1):16. https://doi.org/10.5751/ACE-01013-120116 Copyright $(C 2017$ by the author(s). Published here under license by the Resilience Alliance.

Research Paper

\title{
Mobbing call experiment suggests the enhancement of forest bird movement by tree cover in urban landscapes across seasons
}

\author{
Atsushi Shimazaki ${ }^{1}$, Yuichi Yamaura ${ }^{2}$, Masayuki Senzaki ${ }^{1,3}$, Yuki Yabuhara ${ }^{1}$ and Futoshi Nakamura ${ }^{1}$ \\ ${ }^{1}$ Graduate School of Agriculture, Hokkaido University, ${ }^{2}$ Department of Forest Vegetation, Forestry and Forest Products Research \\ Institute, ${ }^{3}$ Center for Environmental Biology and Ecosystem Studies, National Institute for Environmental Studies
}

\begin{abstract}
Local scale movement behavior is an important basis to predict large-scale bird movements in heterogeneous landscapes. Here we conducted playback experiments using mobbing calls to estimate the probability that forest birds would cross a 50-m urban area during three seasons (breeding, dispersal, and wintering seasons) with varying amounts of tree cover, building area, and electric wire density. We examined the responses of four forest resident species: Marsh Tit (Poecile palustris), Varied Tit (Sittiparus varius), Japanese Tit (P. minor), and Eurasian Nuthatch (Sitta europaea) in central Hokkaido, northern Japan. We carried out and analyzed 250 playback experiments that attracted 618 individuals. Our results showed that tree cover increased the crossing probability of three species other than Varied Tit. Building area and electric wire density had no detectable effect on crossing probability for four species. Seasonal difference in the crossing probability was found only for Varied Tit, and the probability was the highest in the breeding season. These results suggest that the positive effect of tree cover on the crossing probability would be consistent across seasons. We therefore conclude that planting trees would be an effective way to promote forest bird movement within an urban landscape.
\end{abstract}

\section{Expérimentation de cris de houspillage suggère une augmentation des mouvement d'oiseaux selon le couvert forestier dans des paysages urbains en toutes saisons.}

RÉSUMÉ. Les comportements de déplacements à l'échelle locale sont importants car ils servent de base afin de prédire les déplacements à grande échelle d'oiseaux dans des paysages hétérogènes. Nous avons utilisé des enregistrements de cris de houspillage afin d'estimer la probabilité que des oiseaux forestiers traversent une zone urbaine de 50-m lors de trois saisons (reproduction, dispersement, ainsi que hivernage) avec différent couvert forestier, zones de bâtiments, et densité de fils électriques. Nous avons examiné les réponses de quatre espèces résidentes : mésange nonette (Poecile palustris), mésange variée (Sittiparus varius), mésange de Chine (P.minor), ainsi que la sitelle de Naga (Sitta europaea) en Hokkaido Centrale, au nord du Japon. Nous avons effectué et analysé 250 enregistrements qui ont attiré 618 individus. Nos résultats démontrent que le couvert forestier augmente la probabilité d'une traverse pour trois espèces, autre que la mésange variée. Les zones de bâtiments ainsi que la densité des fils électriques n'ont pas d'effet détectable sur la probabilité de traverse des quatre espèces. Une différence saisonnière fut discernée seulement pour la mésange variée, et la probabilité la plus élevée est durant la saison de reproduction. Ces résultats suggèrent que l'effet positif d'un couvert forestier pour une traverse serait consistent durant toutes les saisons. Nous concluons donc que planter des arbres serait une mesure effective pour favoriser le mouvement des oiseaux forestiers en milieu urbain.

Key Words: breeding season; building area; dispersal season; Hokkaido; wintering season

\section{INTRODUCTION}

Movement, or a change in the spatial location of an organism, is a fundamental ecological process that determines the distribution, population dynamics, and community structure of organisms (Clobert et al. 2001, Nathan et al. 2008). As fragmentation of habitats proceeds, movement of individuals between habitats becomes impeded (Bélisle et al. 2001, Creegan and Osborne 2005), and the risk of extinction of regional and local populations increases (Fahrig 1998, Ferraz et al. 2007). Rapid changes in land use cause habitat loss and degradation as well as habitat fragmentation (Haddad et al. 2015, Newbold et al. 2015). Thus, how the movement of organisms among habitats can be enhanced is a matter of great concern.
Urban areas, which are among the most intensely used land, are often characterized by fragmented landscapes consisting of various dispersal habitats and a variety of factors that limit the movement of organisms, such as residential areas and pavement (Hodgson et al. 2007, Tremblay and St. Clair 2009, 2011). Thus, connectivity between isolated breeding habitats is a function of distance between them and the configuration of the elements comprising urban landscapes (Adriaensen et al. 2003). It also has been suggested that the density of the tree canopy (Gillies et al. 2011), building areas (Hodgson et al. 2007), and electric wire density (Shimazaki et al. 2016) can affect bird movement in urban landscapes. In addition, bird movement behaviors (Krebs 1971, Ekman et al. 1981, Siffczyk et al. 2003) as well as urban environments vary among seasons in urban environments. 
In this study, we conducted playback experiments using mobbing calls (Desrochers and Hannon 1997, Bélisle and Desrochers 2002, Clair 2003) in experimental plots with different amounts of three urban elements (tree cover, buildings, and electric wire) during three seasons (breeding, dispersal, and wintering) and estimated the effects of these elements and seasons on the probability of forest birds to cross 50-m distances embedded in the urban area. This can be an important step to predict large-scale bird movements in heterogeneous landscapes based on the empirically measured movement data (Haddad 1999, Shimazaki et al. 2016) because habitat quality cannot be a reliable indicator of movement resistances (Haddad and Tewksbury 2005, Keeley et al. 2016, Ziółkowska et al. 2016).

\section{METHODS}

\section{Mobbing call and its recording}

Our focal species were Marsh Tit (Poecile palustris), Varied Tit (Sittiparus varius), Japanese Tit ( $P$. minor), and Eurasian Nuthatch (Sitta europaea), which are resident forest generalist species (hereafter: focal species). We recorded the mobbing calls of focal species ( 5 Marsh Tits, 2 Varied Tits, a Japanese Tit, and 2 Eurasian Nuthatches) and two other species, a Great Spotted Woodpecker (Dendrocopos major) and a Eurasian Treecreeper (Certhia familiaris), for $30 \mathrm{sec}$ using a perched stuffed Ural Owl (Strix uralensis), which is one of the dominant predators for our focal species in our study region, in mid-April 2013 at the Tomakomai Experimental Forest of Hokkaido University (Shimazaki et al. 2016). Although it is better to use different recordings in each playback experiment to capture potential variations of mobbing calls in different locations or seasons, because the recording included definitive types of mobbing calls by focal species, we used this single mobbing call recording in all playback experiments (see Appendix 1).

\section{Study area and experimental plots}

We conducted experiments in Sapporo, Hokkaido, Japan $\left(43^{\circ} 3^{\prime}\right.$ $\mathrm{N}, 141^{\circ} 20^{\prime} \mathrm{E}$ ) and six adjacent cities (Otaru, Ebetsu, Ishikari, Kitahirosima, Chitose, and Tomakomai; Fig. 1) to examine the effects of three elements included in the urban landscape on bird movement. Sapporo is the fourth largest city in Japan, with a population of 1.93 million. Sapporo and the six adjacent cities are home to 2.57 million people and form a large urban area in the middle of Hokkaido.

We established $12150 \times 50$-m experimental plots in the study area (Fig. 1). The center of one side of each plot (called the starting point) was positioned at the edge of woodlands $>2$ ha in area, and the center of the opposite side (goal point) was located at a tree. The plots were $50 \times 50$-m square so that the gap crossing probabilities of the birds could be clearly differentiated (Creegan and Osborne 2005, Tremblay and St. Clair 2009). We tried to place the plots at least $400 \mathrm{~m}$ from each other (Tremblay and St. Clair 2009). We used Fundamental Geospatial Data (Geospatial Information Authority of Japan) to measure the ratio of building area $(0-35.8 \%)$ within plots. We used color aerial photographs to manually identify individual tree canopies, and measured the ratio of tree cover $(0-100 \%)$ with Quantum GIS ver. 1.8.0. The photographs were provided by the Geospatial Information Authority of Japan (http://maps.gsi.go.jp/). We visually checked in the fields if buildings and/or tree cover were still present as they were in the past, because at least six years had passed since the data were generated and the photographs taken. We did not use a plot after tree cover and/or building area had been altered during the experimental periods as a consequence of tree felling or a building being demolished. We measured the total length of electric wire in each plot, and treated it as the wire density. The absolute values of Pearson's correlation coefficient of those variables were $\leq 0.55$.

Fig. 1. Study area and experimental plots. We conducted the experiments in Sapporo and six adjacent cities. Dots mean experimental plots.

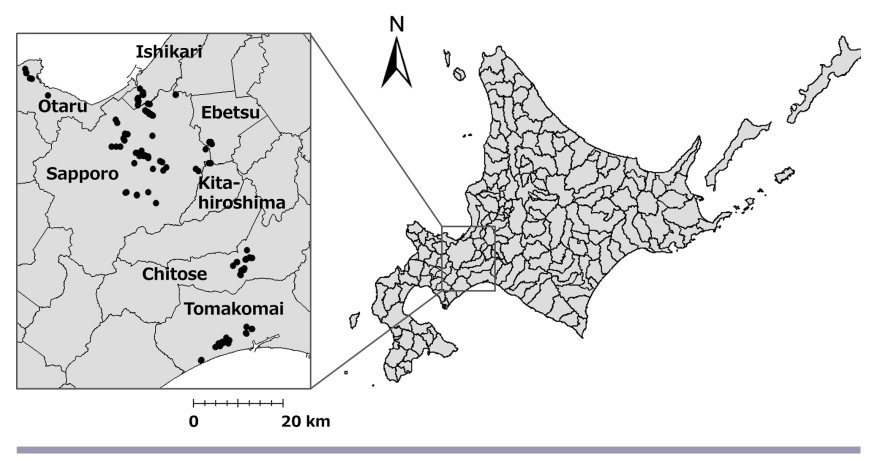

\section{Mobbing call playback experiment}

The first author (A.S.) conducted the experiments with one assistant from $08: 30$ to $16: 00$ on days without heavy rain and/or strong winds (Bélisle and Desrochers 2002, Creegan and Osborne 2005) during three distinct periods: (1) breeding (6 May-17 June 2014); (2) dispersal (1 August-30 September 2014); and (3) wintering (10 December 2014-16 February 2015). We stratified the time of day at which the individual experiments were conducted to avoid the confounding of the effects of covariates and time of day.

We positioned a portable speaker (EUROPORT EPA40; Behringer, Willich, Germany) connected to a player (iPhone4S; Apple, Cupertino, California, USA or NW-E083, Sony, Tokyo, Japan) at the starting (S) and goal (G) points within $1 \mathrm{~m}$ from the ground and oriented the speakers to the woodland and $\mathrm{S}$ points, respectively. After positioning the speakers, we started playbacks at the $S$ points and recorded the birds attracted within $10 \mathrm{~m}$ of the $\mathrm{S}$ points. We continued to play the call for 6 min unless $1 \mathrm{~min}$ had passed since the last new individual was attracted. Immediately after we stopped playing the call at the $S$ points, the speaker at the $G$ points was turned on to play the call. Then we recorded birds crossing the plots from the $S$ to the $G$ points. If multiple individuals of the same species formed a flock or pair, they were treated as one individual to avoid the problem of pseudoreplication. We ceased the experiment and did not collect the data when tits formed a flock ambiguously (e.g., large time lag between individuals of the same flock crossing the plot) or multispecific flocks formed. The call was stopped when $6 \mathrm{~min}$ had passed or all birds had crossed the plots from the $S$ to the $G$ points. We did not record individuals flying from anywhere other than the $\mathrm{S}$ to the $\mathrm{G}$ points. Playback volume was adjusted to $60 \mathrm{~dB}$ (= environmental quality standards for noise in Sapporo city) at 5 
Table 1. Number of experiments and individuals attracted to start and goal points of each seasons and species.

\begin{tabular}{|c|c|c|c|c|c|}
\hline Species & Season & Number of experiment ${ }^{\dagger}$ & $\begin{array}{l}\text { Number at } \\
\text { start point }\end{array}$ & $\begin{array}{l}\text { Number at } \\
\text { goal point }\end{array}$ & $\overline{\text { Crossing probability }}$ \\
\hline \multirow[t]{3}{*}{ Japanese Tit } & Breeding & 55 & 83 & 46 & 0.55 \\
\hline & Dispersal & 46 & 59 & 27 & 0.46 \\
\hline & Wintering & 40 & 70 & 27 & 0.39 \\
\hline \multirow[t]{3}{*}{ Marsh Tit } & Breeding & 42 & 58 & 29 & 0.50 \\
\hline & Dispersal & 48 & 70 & 29 & 0.41 \\
\hline & Wintering & 33 & 47 & 21 & 0.45 \\
\hline \multirow[t]{3}{*}{ Varied Tit } & Breeding & 29 & 34 & 29 & 0.85 \\
\hline & Dispersal & 47 & 60 & 38 & 0.63 \\
\hline & Wintering & 32 & 53 & 25 & 0.47 \\
\hline \multirow{3}{*}{ Nuthatch } & Breeding & 14 & 14 & 9 & 0.64 \\
\hline & Dispersal & 29 & 36 & 17 & 0.47 \\
\hline & Wintering & 24 & 34 & 11 & 0.32 \\
\hline
\end{tabular}

Number of experiments when focal species were successfully attracted to start point.

Number of individuals attracted to start point.

${ }^{\S}$ Number of individuals attracted to goal point from start point.

${ }^{\mathrm{I}}$ Crossing probability obtained by dividing number of individuals at goal point by number of individuals at start point.

$\mathrm{m}$ from the speaker, and we confirmed that surveyor at the $\mathrm{S}$ points heard the playbacks from the G points (Tremblay and St. Clair 2009). We did not conduct a survey if mobbing calls played at the $\mathrm{G}$ point could not be heard at the $\mathrm{S}$ point (Tremblay and St. Clair 2009).

\section{Statistical analysis}

We estimated the effects of tree cover, building area, electric wire density, and season on the probabilities that focal species crossed the plots (crossing probability) using logistic regression analysis. We treated the number of individual birds that were attracted to the $\mathrm{S}$ point in one experiment as the number of trials, and then the number of individuals crossed the plots from the $S$ to the $G$ points among them as the number of successes, and the crossing probability as a success probability of the binomial distribution. We then examined the effects of the predictor variables (tree cover, building area, electric wire density, and season) on the crossing probability. We constructed models for all possible combinations of variables, ranked them using Akaike's information criterion (AIC), and considered significant variables in the best model as meaningful predictor variables. However, we averaged the models if there were multiple well-supported models whose delta AIC scores were $<2$, and significant variables in the averaged model were considered meaningful predictor variables. We calculated support for each model as Akaike weight $\left(\mathrm{w}_{\mathrm{i}}\right)$ and computed a single coefficient using the $\mathrm{w}_{\mathrm{i}}$ weighted average and the coefficient of each model. We assumed that all variables were included in every model, so the coefficient corresponding to a variable that was not selected was set to zero in some models. We used R (ver. 3.2.0) and 'MuMIn'R package (ver. 1.15.1) for the model selection and averaging.

\section{RESULTS}

We carried out the playback experiments 250 times and observed 618 individuals for the analysis (Table 1). The model selection result showed several models that were well supported, with delta AIC scores < 2 for all focal species (Japanese Tit: six models; Marsh Tit: four models; Varied Tit: five models; and Eurasian nuthatch: six models: Appendix 2). Crossing probability was estimated to be the highest in the breeding season among the three seasons for Varied Tit (Table 2). The building area and electric wire density were not associated with the crossing probability of any of the focal species, and the RVI (Relative Variable Importance) of these variables was mostly low. The crossing probabilities of three focal species other than Varied Tit were significantly positively associated with the tree cover (Fig. 2; Table 2 ). When the interaction between the tree cover and season was added as a variable in the averaged model for focal species, no significant interaction terms were detected (Appendix 3).

Fig. 2. Relationship between the ratio of tree cover and crossing probability of four focal species. The continuous variable other than the tree cover were set to average and the season was set to dispersal season.
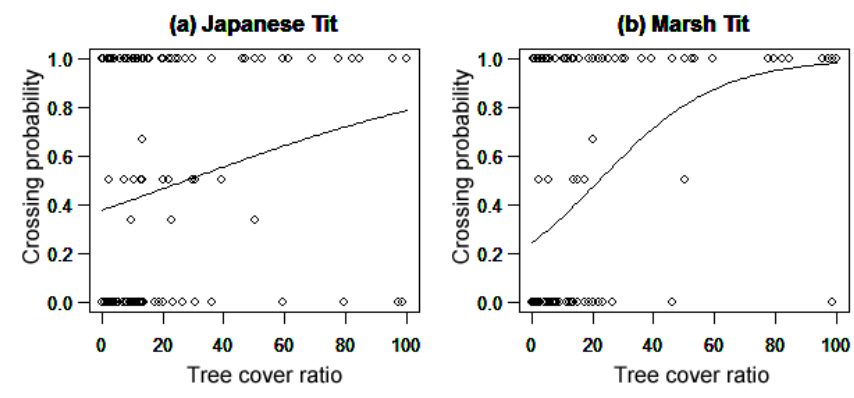

(c) Varied Tit

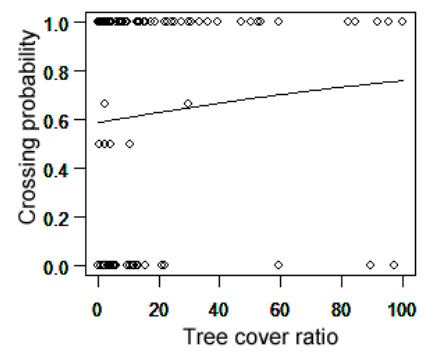

(d) Eurasian Nuthatch

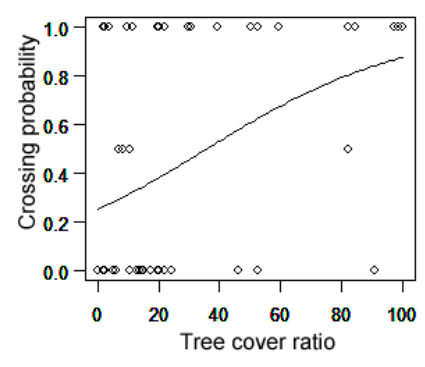


Table 2. Results of model averaging for four species in three seasons.

\begin{tabular}{|c|c|c|c|c|c|c|c|}
\hline Species & Parameter & Estimate & SE & z-value & p-value & & $\mathrm{RVI}^{\|}$ \\
\hline \multirow{6}{*}{ Japanese tit } & Intercept & -0.43 & 0.41 & 1.05 & 0.29 & & \\
\hline & Electric wire ${ }^{\dagger}$ & 0.0016 & 0.0016 & 0.98 & 0.33 & & 0.68 \\
\hline & Tree ${ }^{\ddagger}$ & 0.018 & 0.008 & 2.34 & 0.02 & $*$ & 1.00 \\
\hline & Building $^{\S}$ & -0.005 & 0.013 & 0.39 & 0.70 & & 0.26 \\
\hline & Dispersal & -0.24 & 0.34 & 0.69 & 0.49 & & 0.53 \\
\hline & Wintering & -0.35 & 0.41 & 0.85 & 0.40 & & \\
\hline \multirow{4}{*}{ Marsh tit } & Intercept & -1.32 & 0.47 & 2.78 & 0.01 & $* *$ & \\
\hline & Electric wire $^{\dagger}$ & -0.0003 & 0.0011 & 0.28 & 0.78 & & 0.31 \\
\hline & Tree ${ }^{\ddagger}$ & 0.052 & 0.011 & 4.57 & 0.00 & $* * *$ & 1.00 \\
\hline & Building ${ }^{\S}$ & 0.016 & 0.022 & 0.72 & 0.47 & & 0.51 \\
\hline \multirow[t]{6}{*}{ Varied tit } & Intercept & 1.67 & 0.60 & 2.78 & 0.01 & $* *$ & \\
\hline & Electric wire $^{\dagger}$ & 0.0002 & 0.0008 & 0.22 & 0.82 & & 0.16 \\
\hline & Tree ${ }^{\ddagger}$ & 0.009 & 0.010 & 0.91 & 0.36 & & 0.64 \\
\hline & Building $^{\S}$ & -0.005 & 0.014 & 0.36 & 0.72 & & 0.30 \\
\hline & Dispersal & -1.27 & 0.56 & 2.24 & 0.03 & $*$ & 1.00 \\
\hline & Wintering & -1.86 & 0.56 & 3.27 & 0.00 & $* *$ & \\
\hline \multirow[t]{6}{*}{ Nuthatch } & Intercept & -0.83 & 0.79 & 1.03 & 0.30 & & \\
\hline & Electric wire $^{\dagger}$ & 0.0008 & 0.0019 & 0.44 & 0.66 & & 0.32 \\
\hline & Tree ${ }^{*}$ & 0.031 & 0.010 & 3.11 & 0.00 & $* *$ & 1.00 \\
\hline & Building ${ }^{\S}$ & 0.001 & 0.015 & 0.07 & 0.94 & & 0.19 \\
\hline & Dispersal & -0.39 & 0.63 & 0.61 & 0.54 & & 0.50 \\
\hline & Winteringl & -0.69 & 0.86 & 0.80 & 0.43 & & \\
\hline $\begin{array}{l}{ }^{* * *}<0.001, \\
{ }^{\dagger} \text { Effect of el } \\
{ }^{\star} \text { Effect of tre } \\
{ }^{\S} \text { Effect of bu } \\
\text { |Effect of dis } \\
{ }^{\|} \text {Relative var }\end{array}$ & $\begin{array}{l}\text { d wintering seas } \\
\text { ortance (single }\end{array}$ & d with bree & ason. & (a) & & & \\
\hline
\end{tabular}

\section{DISCUSSION}

The tree cover had a positive effect on the crossing probabilities of the focal species other than Varied Tit, suggesting that planting trees effectively would promote forest bird movement in urban landscapes (Fig. 2), fitting well with previous studies showing that forest birds use individual trees or small patches as stepping stones in agricultural landscapes (Gillies et al. 2011) and our previous study in the same urban area (Shimazaki et al. 2016). Although we did not formally identify the tree species in the study area, broad-leaved tree species dominated the trees in the urban area. We observed that individual birds used coniferous trees as the perches during the experiments (A. Shimazaki, personal observation). However, forest birds can have preferences in tree species (Holmes and Robinson 1981, Yoshii et al. 2015), and what tree species are planted may be important for the gap-crossing behavior as well as bird movements in urban area. For example, in Japan, Coal Tit (Periparus ater) and Goldcrest (Regulus regulus) are known as specialists of coniferous trees, and their abundance is higher in conifer plantations than in natural forests dominated by broad-leaved forests, though abundance of most species and therefore bird species richness are higher in natural forests (Yamaura et al. 2008, 2009). These suggest that planting broadleaved trees may be beneficial for many bird species.

The result showing that the building area was not significant in the models for any of the focal species indicates that building density has only minor effects on the crossing probabilities of forest birds. However, our previous study found that increasing building area facilitates movement of tits and nuthatches compared to open areas (Shimazaki et al. 2016), and Hodgson et al. (2007) showed that omnivores and nectarivores are more likely to penetrate edges adjoining high-density housing than those adjacent to low-density housing. In our previous study, we did not measure the electric wire length as we did here, and in this study wire density was the second most important variable for Japanese Tit (Table 2). Thus, the effect of building on bird movement might be confounded with that of electric wire. It seems that Psittaciformes and Passeriformes, which were the focus of Hodgson et al. (2007) and are distributed in the southern hemisphere, had different behavioral traits from our focal species, so they responded differently to increased building density.

The crossing probabilities of Varied Tit during the dispersal and wintering seasons were significantly lower than those during the breeding season. Other species also showed the similar seasonal effects though their effects were not significant (Table 2). Because the focal species form and defend territories during the breeding season (Krebs 1971), the strong response to our mobbing playback may be due to territorial aggression of respondents toward perceived intruders. Therefore, the seasonal effect on gap crossing behavior may not be due entirely to a change in gap permeability as much as to a change in testosterone levels. This is where the scale of studies like ours must be extrapolated carefully to larger scale connectivity, given that playback studies in general only test within-territory movement behavior (e.g., Sieving et al. 1996). The interaction between the tree cover and season was not supported in any of these focal species, suggesting that the positive effect of tree cover on the movement of forest birds was consistent across seasons. 
We conducted a playback experiment and inferred bird movements at a 50-m scale. Although these small-scale behavioral decisions can be easily measured as the basis of the large-scale predictions (Lima and Zollner 1996, Haddad 1999, Bélisle and Desrochers 2002), large-scale movements may be driven by different motivations and cues, and cannot be extrapolated from small-scale behavioral studies (Desrochers et al. 1999, Zollner 2000, Bélisle 2005, Abrahms et al. 2017). Therefore, our results should be used alongside those generated by other approaches including large-scale translocations (Bélisle et al. 2001, Castellón and Sieving 2006, Gillies and St. Clair 2008), observation of spontaneous movements of birds (Grubb and Doherty 1999, Lees and Peres 2009), and species distributions (Watling et al. 2011).

Responses to this article can be read online at: http://www.ace-eco.org/issues/responses.php/1013

\section{Acknowledgments:}

The authors would like to thank the members of the Forest Ecosystem Management Laboratory of Hokkaido University for their field assistance and helpful discussions during the study. Comments from Ryan Norris, Subject Editor, and an anonymous reviewer greatly improved the manuscript. A. Unno and T. Furukawa provided useful comments on the manuscript. Residents around the experimental plots are particularly to be thanked for permission to conduct our experiments. This study was partially supported by JSPS KAKENHI Grant 23248021 and 14J05368.

\section{LITERATURE CITED}

Abrahms, B., S. C. Sawyer, N. R. Jordan, J. W. McNutt, A. M. Wilson, and J. S. Brashares. 2017. Does wildlife resource selection accurately inform corridor conservation? Journal of Applied Ecology 54:412-422. http://dx.doi.org/10.1111/1365-2664.12714

Adriaensen, F., J. P. Chardon, G. De Blust, E. Swinnen, S. Villalba, H. Gulinck, and E. Matthysen. 2003. The application of 'leastcost' modelling as a functional landscape model. Landscape and Urban Planning 64:233-247. http://dx.doi.org/10.1016/S0169-2046 (02)00242-6

Bélisle, M. 2005. Measuring landscape connectivity: the challenge of behavioral landscape ecology. Ecology 86:1988-1995. http://dx. doi.org/10.1890/04-0923

Bélisle, M., and A. Desrochers. 2002. Gap-crossing decisions by forest birds: an empirical basis for parametrizing spatiallyexplicit, individual-based model. Landscape Ecology 17:219-231. http://dx.doi.org/10.1023/A:1020260326889

Bélisle, M., A. Desrochers, and M.-J. Fortin. 2001. Influence of forest cover on the movements of forest birds: a homing experiment. Ecology 82:1893-1904. http://dx.doi.org/10.1890/0012-9658 (2001)082[1893:IOFCOT]2.0.CO;2

Castellón, T. D., and K. E. Sieving. 2006. An experimentally test of matrix permeability and corridor use by an endemic understory bird. Conservation Biology 20:135-145. http://dx.doi.org/10.1111/ j.1523-1739.2006.00332.x
Clair, C. C. S. 2003. Comparative permeability of roads, rivers, and meadows to songbirds in Banff National Park. Conservation Biology 17:1151-1160. http://dx.doi.org/10.1046/j.1523-1739.2003.02156. $\mathrm{x}$

Clobert, J., E. Danchin, A. A. Dhondt, and J. D. Nichols. 2001. Dispersal. Oxford University Press, Oxford, UK.

Creegan, H. P., and P. E. Osborne. 2005. Gap-crossing decisions of woodland songbirds in Scotland: an experimental approach. Journal of Applied Ecology 42:678-687. http://dx.doi.org/10.1111/ j.1365-2664.2005.01057.x

Desrochers, A., and S. J. Hannon. 1997. Gap crossing decisions by forest songbirds during the post-fledging period. Conservation Biology 11:1204-1210. http://dx.doi.org/10.1046/j.1523-1739.1997.96187. $\mathrm{x}$

Desrochers, A., S. J. Hannon, M. Bélisle, and C. C. St. Clair. 1999. Movement of songbirds in fragmented forests: can we "scale up" from behaviour to explain occupancy patterns in the landscape? Pages 2447-2464 in N. J. Adams, and R. H. Slotow, editor. Proceedings of the 22nd International Ornithological Congress, Durban. BirdLife South Africa, Johannesburg, South Africa.

Ekman, J., G. Cederholm, and C. Askenmo. 1981. Spacing and survival in winter groups of Willow Tit Parus montanus and Crested Tit $P$. cristatus - a removal study. Journal of Animal Ecology 50:1-9. http://dx.doi.org/10.2307/4027

Fahrig, L. 1998. When does fragmentation of breeding habitat affect population survival? Ecological Modelling 105:273-292. http://dx.doi.org/10.1016/S0304-3800(97)00163-4

Ferraz, G., J. D. Nichols, J. E. Hines, P. C. Stouffer, R. O. Bierregaard Jr, and T. E. Lovejoy. 2007. A large-scale deforestation experiment: effects of patch area and isolation on Amazon birds. Science 315:238-241. http://dx.doi.org/10.1126/ science. 1133097

Gillies, C. S., H. L. Beyer, and C. C. St. Clair. 2011. Fine-scale movement decisions of tropical forest birds in a fragmented landscape. Ecological Applications 21:944-954. http://dx.doi. org/10.1890/09-2090.1

Gillies, C. S., and C. C. St. Clair. 2008. Riparian corridors enhance movement of a forest specialist bird in fragmented tropical forest. Proceedings of the National Academy of Sciences 105:19774-19779. http://dx.doi.org/10.1073/pnas.0803530105

Grubb, T. C. Jr, and P. F. Doherty Jr. 1999. On home-range gapcrossing. Auk 116:618-628. http://dx.doi.org/10.2307/4089323

Haddad, N. M. 1999. Corridor use predicted from behaviors at habitat boundaries. American Naturalist 153:215-227. http://dx. doi.org/10.1086/303163

Haddad, N. M., L. A. Brudvig, J. Clobert, K. F. Davies, A. Gonzalez, R. D. Holt, T. E. Lovejoy, J. O. Sexton, M. P. Austin, C. D. Collins, W. M. Cook, E. I. Damschen, R. M. Ewers, B. L. Foster, C. N. Jenkins, A. J. King, W. F. Laurance, D. J. Levey, C. R. Margules, B. A. Melbourne, A. O. Nicholls, J. L. Orrock, D.X. Song, and J. R. Townshend. 2015. Habitat fragmentation and its lasting impact on Earth's ecosystems. Science Advances 1: e1500052. http://dx.doi.org/10.1126/sciadv.1500052 
Haddad, N. M., and J. J. Tewksbury. 2005. Low-quality habitat corridors as movement conduits for two butterfly species. Ecological Applications 15:250-257. http://dx.doi.org/10.1890/03-5327

Hodgson, P., K. French, and R. E. Major. 2007. Avian movement across abrupt ecological edges: differential responses to housing density in an urban matrix. Landscape and Urban Planning 79:266-272. http://dx.doi.org/10.1016/j.landurbplan.2006.02.012

Holmes, R. T., and S. K. Robinson. 1981. Tree species preferences of foraging insectivorous birds in a northern hardwood forest. Oecologia 48:31-35. http://dx.doi.org/10.1007/BF00346985

Keeley, A. T. H., P. Beier, and J. W. Gagnon. 2016. Estimating landscape resistance from habitat suitability: effects of data source and nonlinearities. Landscape Ecology 31:2151-2162. http://dx.doi.org/10.1007/s10980-016-0387-5

Krebs, J. R. 1971. Territory and breeding density in the Great Tit, Parus major L. Ecology 52:3-22. http://dx.doi.org/10.2307/1934734

Lees, A. C., and C. A. Peres. 2009. Gap-crossing movements predict species occupancy in Amazonian forest fragments. Oikos 118:280-290. http://dx.doi.org/10.1111/j.1600-0706.2008.16842. $\mathrm{x}$

Lima, S. L., and P. A. Zollner. 1996. Towards a behavioral ecology of ecological landscapes. Trends in Ecology and Evolution 11:131-135. http://dx.doi.org/10.1016/0169-5347(96)81094-9

Nathan, R., W. M. Getz, E. Revilla, M. Holyoak, R. Kadmon, D. Saltz, and P. E. Smouse. 2008. A movement ecology paradigm for unifying organismal movement research. Proceedings of the National Academy of Sciences 105:19052-19059. http://dx.doi. org/10.1073/pnas.0800375105

Newbold, T., L. N. Hudson, S. L. L. Hill, S. Contu, I. Lysenko, R. A. Senior, L. Börger, D. J. Bennett, A. Choimes, B. Collen, J. Day, A. De Palma, S. Diaz, S. Echeverria-Londoño, M. J. Edgar, A. Feldman, M. Garon, M. L. K. Harrison, T. Alhusseini, D. J. Ingram, Y. Itescu, J. Kattge, V. Kemp, L. Kirkpatrick, M. Kleyer, D. L. P. Correia, C. D. Martin, S. Meiri, M. Novosolov, Y. Pan, H. R. P. Phillips, D. W. Purves, A. Robinson, J. Simpson, S. L. Tuck, E. Weiher, H. J. White, R. M. Ewers, G. M. Mace, J. P. W. Scharlemann, and A. Purvis. 2015. Global effects of land use on local terrestrial biodiversity. Nature 520:45-50. http://dx.doi. org/10.1038/nature14324

Shimazaki, A., Y. Yamaura, M. Senzaki, Y. Yabuhara, T. Akasaka, and F. Nakamura. 2016. Urban permeability for birds: an approach combining mobbing-call experiments and circuit theory. Urban Forestry \& Urban Greening 19:167-175. http://dx. doi.org/10.1016/j.ufug.2016.06.024

Sieving, K. E., M. F. Willson, and T. L. De Santo. 1996. Habitat barriers to movement of understory birds in fragmented southtemperate rainforest. Auk 113:944-949. http://dx.doi.org/10.2307/4088877
Siffczyk, C., L. Brotons, K. Kangas, and M. Orell. 2003. Home range size of Willow Tits: a response to winter habitat loss. Oecologia 136:635-642. http://dx.doi.org/10.1007/s00442-003-1256$\mathrm{x}$

Tremblay, M. A., and C. C. St. Clair. 2009. Factors affecting the permeability of transportation and riparian corridors to the movements of songbirds in an urban landscape. Journal of Applied Ecology 46:1314-1322. http://dx.doi.org/10.1111/ j.1365-2664.2009.01717.x

Tremblay, M. A., and C. C. St. Clair. 2011. Permeability of a heterogeneous urban landscape to the movements of forest songbirds. Journal of Applied Ecology 48:679-688. http://dx.doi. org/10.1111/j.1365-2664.2011.01978.x

Watling, J. I., A. J. Nowakowski, M. A. Donnelly, and J. L. Orrock. 2011. Meta-analysis reveals the importance of matrix composition for animals in fragmented habitat. Global Ecology and Biogeography 20:209-217. http://dx.doi.org/10.1111/ j.1466-8238.2010.00586.X

Yamaura, Y., S. Ikeno, M. Sano, K. Okabe, and K. Ozaki. 2009. Bird responses to broad-leaved forest patch area in a plantation landscape across seasons. Biological Conservation 142:2155-2165. http://dx.doi.org/10.1016/j.biocon.2009.04.015

Yamaura, Y., K. Katoh, and T. Takahashi. 2008. Effects of stand, landscape, and spatial variables on bird communities in larch plantations and deciduous forests in central Japan. Canadian Journal of Forest Research 38:1223-1243. http://dx.doi. org/10.1139/X07-226

Yoshii, C., Y. Yamaura, M. Soga, M. Shibuya, and F. Nakamura. 2015. Comparable benefits of land sparing and sharing indicated by bird responses to stand-level plantation intensity in Hokkaido, northern Japan. Journal of Forest Research 20:167-174. http://dx. doi.org/10.1007/s10310-014-0453-2

Ziółkowska, E., K. Ostapowicz, V. C. Radeloff, T. Kuemmerle, A. Sergiel, T. Zwijacz-Kozica, F. Zięba, W. Śmietana, and N. Selva. 2016. Assessing differences in connectivity based on habitat versus movement models for brown bears in the Carpathians. Landscape Ecology 31:1863-1882. http://dx.doi.org/10.1007/ s10980-016-0368-8

Zollner, P. A. 2000. Comparing the landscape level perceptual abilities of forest sciurids in fragmented agricultural landscapes. Landscape Ecology 15:523-533. http://dx.doi.org/10.1023/ A:1008154532512
Editor-in-Chief: Ryan Norris Subject Editor: Katie E.Sieving

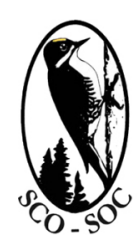

Sponsored by the Society of Canadian Ornithologists and Bird Studies Canada Parrainée par la Société des ornithologistes du Canada et Études d'oiseaux Canada

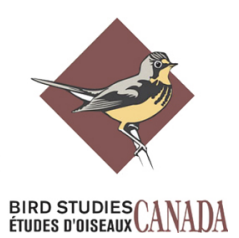


Appendix 1. Details of the mobbing call recording in the playback experiments.

\section{Objectives}

Although it is desired to use different recording in each playback experiment (Kroodsma et al., 2001), we used a single mobbing call recording recorded in the breeding season in all playback experiments. To justify this, we assessed whether the recording can be considered a representative of mobbing calls of our focal species. Specifically, using many available mobbing call recordings in xeno-canto (http://www.xeno-canto.org/, accessed at 0130-2017), we compared the number of discrete mobbing calls of our focal species in our recording with those in other regions because the Paridae species has several types of mobbing calls that might convey different information (Hailman, 1989). In addition, we examined whether the number of discrete mobbing calls differs between breeding and non-breeding seasons. In these assessments, we focused on one of our focal species (the marsh tit) for following reasons: 1) it is known that various species including the family Paridae respond to not only conspecific mobbing calls but also interspecific ones (e.g., Bélisle and Desrochers, 2002). 2) The marsh tit has wide distribution range across the old world as well as is one of the most common Paridae species in our study region. The following analyses were performed using Adobe Audition 3.0 software and R software (ver. 3.2.0) with "tuneR" and "seewave" packages.

\section{Compiling mobbing call recordings from xeno-canto}

In available recordings of the marsh tit in xeno-canto, we compiled 43 mobbing call recordings which were originally categorized as "alarm call" or "aggression call". Of these, we excluded recordings with high levels of background noise (e.g., wind noise, other bird calls) from further analyses. We also excluded recordings that accompanied with marsh tits' songs because "alarm calls" uttered in such situation might convey different information compared to those uttered to predators. As a result, we used 30 mobbing call recordings (mean recording times $(\mathrm{sec}) \pm$ Standard Deviation $=60.40 \pm 39.78$ ) recorded in several countries (14 in Germany, 9 in Poland, 3 in France, 
2 in Netherlands, 1 in Czech and Sweden) in the following analyses.

\section{Comparisons of the number of discrete mobbing calls in different locations and} seasons

Based on the sound spectrograms, we counted the number of spectrally discrete mobbing calls for our single recording, all xeno-canto recordings (hereafter the xenocanto recordings, $\mathrm{n}=30$ ), and subsets of the xeno-canto recordings in the breeding season (March to August, hereafter the nonbreeding recordings, $n=8$ ) and in the nonbreeding season (September to February, hereafter the nonbreeding recordings, $n=22$ ).

We identified four spectrally different types of mobbing calls of the marsh tit in all recordings we assessed (Fig A1.1). Hereafter, we referred to each type of mobbing calls as type I, II, III, and IV calls, respectively. Among them, our 30-sec recording included three types of mobbing calls (types I, II and III). Specifically, the recording included 20 type I calls, 13 type II calls and 6 type III calls. The type I calls consisted of a single "tiii" note (Fig A1.1a). The type II calls consisted of a single "chicka" note and various number of "dee" notes (Fig A1.1b), which is an important metric of Paridae's mobbing call quality (Courter and Ritchison, 2010). The number of "dee" notes in type II calls (mean $\pm \mathrm{SD}$ ) was $2.31 \pm 1.18$ (Range: $0-5$ ). The type III calls consisted of multiple "jee" notes (Fig A1.1c) and the number of "jee" notes (mean \pm SD) was $9.50 \pm$ 3.27 (Range: 5-13). The xeno-canto recordings, the nonbreeding recordings and the breeding recordings had four different types of mobbing calls (types I, II, III and IV). The mean numbers of different types of mobbing calls $( \pm S D)$ were $1.30 \pm 0.47$ in the xeno-canto recordings $(n=30), 1.26 \pm 0.49$ in the breeding recordings $(n=8)$ and 1.30 \pm 0.47 in the nonbreeding recordings $(\mathrm{n}=22)$. The seasonal difference (breeding vs. non-breeding seasons) was not significant (t-test; $\mathrm{p}=0.77$ ). The type IV calls consisted of multiple "pi" or "picho" notes (Fig A1.1d) and were included in only two recordings, suggesting that this type of mobbing call would be rare. Thus, these results suggest that our single recording includes almost all types of mobbing calls of the marsh tit and there are no seasonal variations of their mobbing calls, indicating that our 30-sec recording can be considered a representative mobbing calls of our focal species. 


\section{References}

Bélisle, M., and A. Desrochers. 2002. Gap-crossing decisions by forest birds: an empirical basis for parametrizing spatially-explicit, individual-based model. Landscape Ecology 17:219-231.

Courter, J. R., and G. Ritchison. 2010. Alarm calls of tufted titmice convey information about predator size and threat. Behavioral Ecology 21:936-942.

Hailman, J. P. 1989. The organization of major vocalizations in the Paridae. Wilson Bulletin 101:305-343.

Kroodsma, D. E., B. E. Byers, E. Goodale, S. Johnson, and W.-C. Liu. 2001. Pseudoreplication in playback experiments, revisited a decade later. Animal Behaviour 61:1029-1033.

(a) Type I call

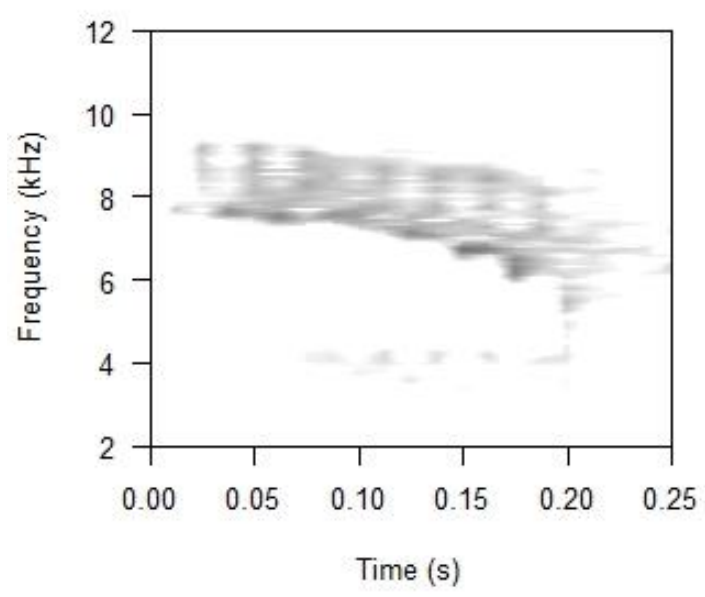

(c) Type III call

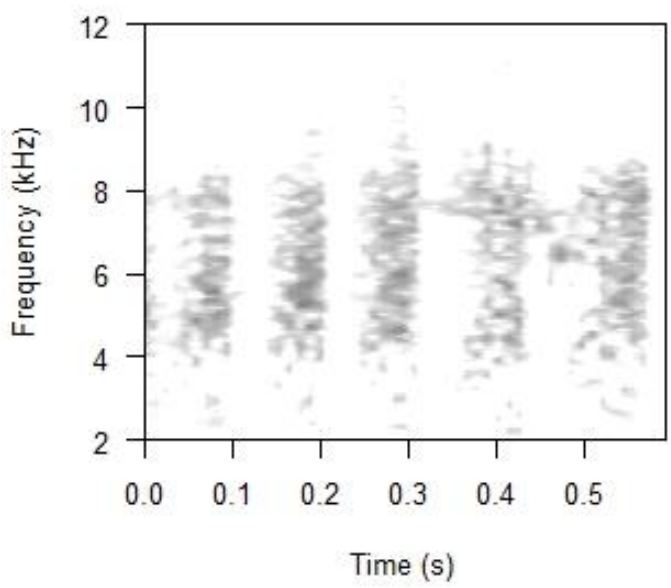

(b) Type II call

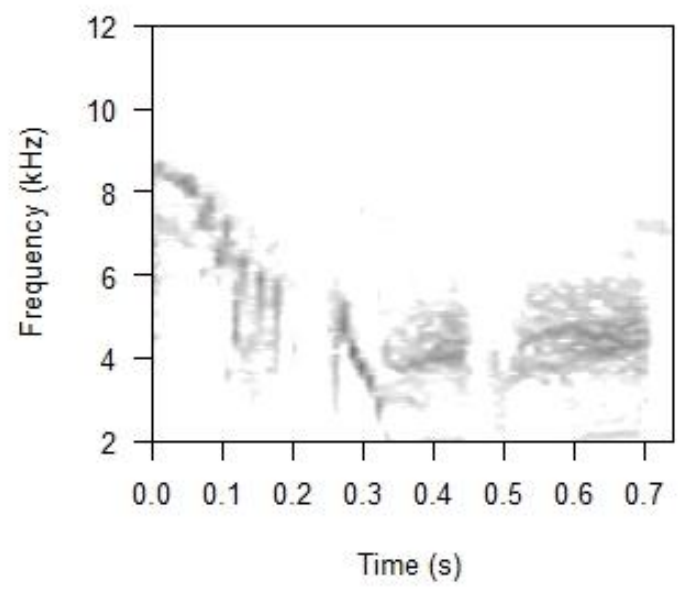

(d) Type IV call

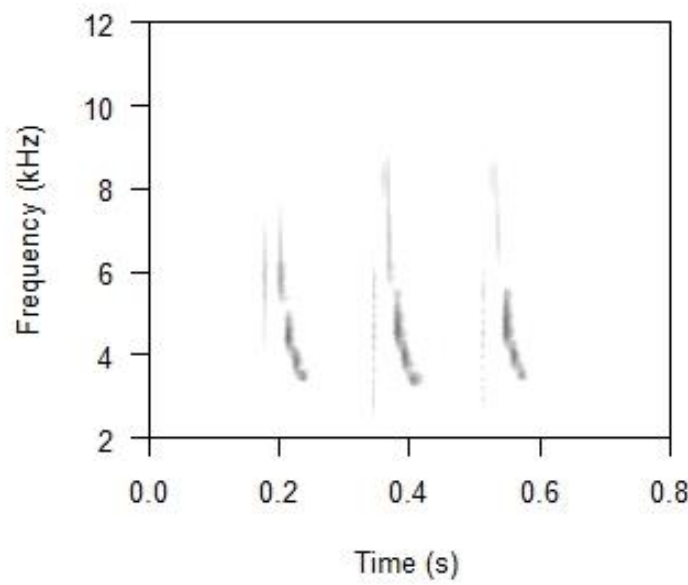

Fig. A1.1. Examples of sound spectrograms of the mobbing calls of the marsh tit. We draw spectrograms of the type I, II, III calls using the recording used in the playback 
experiments. The sound spectrogram of the type IV call was drawn using one of xenocanto recordings (XC127377). 
Appendix 2. Results of model selection for four species.

Appendix A2.1. Results of model selection for four species. Models with delta AIC $<2$ are shown.

\begin{tabular}{|c|c|c|c|c|c|c|c|c|}
\hline Japanese Tit & Intercept & Electric wire $\uparrow$ & Tree $!$ & Building $§$ & Season| & AIC & $\Delta \mathrm{AIC}$ & Weight $\|$ \\
\hline & -0.47 & 0.0022 & 0.020 & & + & 267.7 & 0 & 0.17 \\
\hline & -0.80 & 0.0021 & 0.020 & & & 267.9 & 0.22 & 0.15 \\
\hline & -0.07 & & 0.017 & & + & 268.2 & 0.51 & 0.13 \\
\hline & -0.42 & & 0.017 & & & 268.4 & 0.71 & 0.12 \\
\hline & -0.21 & 0.0027 & 0.017 & -0.020 & + & 268.6 & 0.96 & 0.10 \\
\hline & -0.54 & 0.0027 & 0.017 & -0.020 & & 268.9 & 1.17 & 0.09 \\
\hline \multirow[t]{5}{*}{ Marsh Tit } & Intercept & Electric wire $\dagger$ & Tree $!$ & Building $§$ & Season| & AIC & $\triangle \mathrm{AIC} \rrbracket$ & Weight $\|$ \\
\hline & -1.07 & & 0.049 & & & 195.3 & 0 & 0.30 \\
\hline & -1.62 & & 0.055 & 0.029 & & 195.4 & 0.07 & 0.29 \\
\hline & -1.50 & -0.0014 & 0.054 & 0.035 & & 196.7 & 1.42 & 0.15 \\
\hline & -1.00 & -0.0004 & 0.048 & & & 197.2 & 1.92 & 0.11 \\
\hline \multirow[t]{3}{*}{ Varied Tit } & Intercept & Electric wire $\dagger$ & Tree $!$ & Building $§$ & Season| & AIC & $\Delta \mathrm{AIC} \rrbracket$ & Weight $\|$ \\
\hline & 1.54 & & 0.014 & & + & 175.6 & 0 & 0.27 \\
\hline & 1.76 & & & & + & 176.6 & 1.01 & 0.16 \\
\hline
\end{tabular}




\begin{tabular}{|c|c|c|c|c|c|c|c|c|}
\hline & 2.13 & & & -0.023 & + & 177.1 & 1.53 & 0.13 \\
\hline & 1.35 & 0.0011 & 0.015 & & + & 177.2 & 1.56 & 0.12 \\
\hline & 1.73 & & 0.012 & -0.010 & + & 177.4 & 1.77 & 0.11 \\
\hline \multirow[t]{7}{*}{ Nuthatch } & Intercept & Electric wire $\dagger$ & Tree $!$ & Building $§$ & Season| & AIC & $\Delta \mathrm{AIC}$ & Weight $\|$ \\
\hline & -1.08 & & 0.029 & & & 97 & 0 & 0.22 \\
\hline & -0.22 & & 0.029 & & + & 97.1 & 0.06 & 0.21 \\
\hline & -0.71 & 0.0027 & 0.034 & & + & 97.9 & 0.9 & 0.14 \\
\hline & -1.56 & 0.0026 & 0.033 & & & 98 & 0.94 & 0.14 \\
\hline & -0.44 & & 0.032 & 0.012 & + & 99 & 1.95 & 0.08 \\
\hline & -1.09 & & 0.029 & 0.000 & & 99 & 2 & 0.08 \\
\hline
\end{tabular}

$\dagger$ Effect of electric wire density. $\$$ Effect of tree cover. $\S$ Effect of building area.

|Effect of season (indicating that whether the terms were included or not). |

Differences in AIC with the model having the smallest AIC. "Akaike weights showing the likelihood that the individual model is the best model. 
Appendix 3. Statistical analysis with an interaction between season and the tree cover.

We averaged the models with interaction terms for individual species to consider the possible season-specific effects of tree cover.

Table A3.1. Results of model averaging with interaction between the tree cover and seasons.

\begin{tabular}{|c|c|c|c|c|c|c|}
\hline Species & Parameter & Estimate & $\mathrm{SE}$ & z value & $\mathrm{p}$ value & \\
\hline \multirow[t]{8}{*}{ Japanese tit } & Intercept & -0.31 & 0.46 & 0.67 & 0.50 & \\
\hline & Electric wire $\dagger$ & 0.0016 & 0.0016 & 0.97 & 0.33 & \\
\hline & Tree $!$ & 0.014 & 0.012 & 1.19 & 0.23 & \\
\hline & Building § & -0.005 & 0.013 & 0.39 & 0.70 & \\
\hline & Dispersal| & -0.42 & 0.49 & 0.85 & 0.39 & \\
\hline & Wintering| & -0.56 & 0.55 & 1.02 & 0.31 & \\
\hline & Tree $\times$ Dispersal $\mathbb{\emptyset}$ & 0.007 & 0.014 & 0.47 & 0.64 & \\
\hline & Tree $\times$ Wintering $\mathbb{9}$ & 0.008 & 0.016 & 0.47 & 0.64 & \\
\hline \multirow[t]{4}{*}{ Marsh tit } & Intercept & -1.32 & 0.47 & 2.78 & 0.01 & $* *$ \\
\hline & Electric wire $\dagger$ & 0.000 & 0.001 & 0.28 & 0.78 & \\
\hline & Tree $!$ & 0.052 & 0.011 & 4.57 & 0.00 & $* * *$ \\
\hline & Building § & 0.016 & 0.022 & 0.72 & 0.47 & \\
\hline
\end{tabular}




\begin{tabular}{|c|c|c|c|c|c|c|}
\hline \multirow[t]{8}{*}{ Varied tit } & Intercept & 1.72 & 0.61 & 2.78 & 0.01 & $* *$ \\
\hline & Electric wire $\dagger$ & 0.0002 & 0.0008 & 0.21 & 0.84 & \\
\hline & Tree $!$ & 0.006 & 0.013 & 0.47 & 0.64 & \\
\hline & Building $§$ & -0.004 & 0.013 & 0.34 & 0.74 & \\
\hline & Dispersal| & -1.34 & 0.62 & 2.15 & 0.03 & $*$ \\
\hline & Wintering| & -1.92 & 0.60 & 3.13 & 0.00 & $* *$ \\
\hline & Tree $\times$ Dispersal 9 & 0.004 & 0.013 & 0.31 & 0.76 & \\
\hline & Tree $\times$ Wintering & 0.003 & 0.012 & 0.28 & 0.78 & \\
\hline \multirow[t]{8}{*}{ Nathatch } & Intercept & -0.78 & 0.83 & 0.93 & 0.35 & \\
\hline & Electric wire $\dagger$ & 0.0008 & 0.0019 & 0.43 & 0.67 & \\
\hline & Tree $!$ & 0.034 & 0.018 & 1.86 & 0.06 & \\
\hline & Building $§$ & 0.001 & 0.013 & 0.06 & 0.95 & \\
\hline & Dispersal| & -0.33 & 0.74 & 0.44 & 0.66 & \\
\hline & Wintering| & -0.94 & 1.03 & 0.90 & 0.37 & \\
\hline & Tree $\times$ Dispersal $ף$ & -0.006 & 0.019 & 0.32 & 0.75 & \\
\hline & Tree $\times$ Wintering & 0.002 & 0.017 & 0.11 & 0.91 & \\
\hline
\end{tabular}

The interactions were not included in model of marsh tit (models with interaction terms 
had $>2$ delta AIC).

$\dagger$ Effect of electric wire density. $\$$ Effect of tree cover. $\S$ Effect of building area. |

Effect of dispersal and wintering seasons compared with breeding season. If Effect of interaction between tree cover and dispersal/wintering seasons. 
Appendix 4. Source data and R code to analyze the data.

Please click here to download file 'appendix4.zip'. 